\title{
ПАЛОЧНИКИ КАК ФАКТОР ПОЧВООБРАЗОВАНИЯ
}

Иванюков С.О., Саранчина Н.В., Саранчин Е.П.

Тюменская область, г. Тюмень, ФГКОУ «Тюменское президентское кадетское училище»

Аннотация. Изучение существ - создателей важнейшего компонента жизни на планете - почвы, скорее всего, важная часть подготовки межпланетных космических команд. Работа представляет собой многоплановое исследование, где главным объектом выступает насекомое - Палочник аннамский. Автором проведены наблюдения за пищевой активностью и получены данные о количестве помета, то есть скорости формирования будущего гумуса. Проведено выращивание комнатного растения хлорофитум и оценено влияние смеси песка и гуано палочника на рост листьев и корней. Автору удалось провести серию химических анализов на количество нитратов в полученной «почве». Оценка концентрации нитратов в грунте проводилась как с помощью реагентов, так и с использованием прибора «Соэкс Эковизор F4». C их помощью получены данные о разных по времени формирования «почвах».

Ключевые слова. Палочник аннамский, почвообразование, нитраты, пищевая активность.

\section{Введение}

В лаборатории кабинета биологии ФГКОУ «Тюменское ПКУ» уже пятый год живет колония аннамского палочника. Эти насекомые родом из Индокитая могут служить предметом разных исследований. Кадеты нашего училища уже изучали палочников и ставили опыты по возможности изменения их окраски [1] и анализу пищевых предпочтений. Некрасов Е. [2] глубоко изучил возможность использования грунта из инсектария с палочниками в качестве удобрения для растений. Им были получены интересные данные о влиянии экскрементов палочников на всхожесть растений и проведен анализ содержания основных химических элементов: азота, фосфора и калия в смеси песка и помета насекомых. Автор отмечает значительное количество азота в такой смеси и предлагает использовать её в качестве добавки к почвам. Но, в каком состоянии находится азот в подобной смеси, автор не раскрывает. Как известно [3], азот в почве может находиться в трех формах: аммиачной $\left(\mathrm{NH}_{4}^{+}\right)$, нитритной $\left(\mathrm{NO}_{2}^{-}\right)$и нитратной $\left(\mathrm{NO}_{3}{ }^{-}\right)$. Можно ли предположить, что палочники в ходе своей жизнедеятельности создают в почве или ином грунте среду, благоприятную для роста и развития как бактериальной азотфиксирующей среды, так и для высших растений? Возможно ли создать плодородную почву на основе песка, используя отходы жизнедеятельности палочника аннамского? 
Мы поставили для себя следующую цель: изучить качественный и, по-возможности, количественный состав азотистых веществ в грунте, создаваемым из песка и отходов жизнедеятельности палочника аннамского.

Для реализации этой цели были сформулированы следующие задачи:

1. Изучить пищевую активность палочников.

2. Исследовать влияние грунта на развитие комнатного растения хлорофитум.

3. Провести химический анализ грунта разного возраста на наличие и концентрацию ионов аммония $\left(\mathrm{NH}_{4}^{+}\right)$, нитрит $\left(\mathrm{NO}_{2}^{-}\right)$ионов и нитрат $\left(\mathrm{NO}_{3}^{-}\right)$ионов.

4. Дать оценку возможности использования смеси песка и экскрементов палочника аннамского в качестве удобрения для домашних растений.

Актуальность работы: наиболее прогрессивные страны всерьез двигаются в направлении создания домов как отдельных экосистем. Знаменитый Илон Маск, собираясь осваивать и заселять Марс, вероятно, проводит серьезные исследования в этом направлении. Изучение существ - создателей важнейшего компонента жизни на планете почвы, скорее всего, важная часть подготовки его команды. Нам кажется, что палочники могут претендовать на эту роль, но, конечно, не в одиночку.

Новизна исследования: согласно изученным литературным данным, ранее, исследование содержания разных азотистых веществ в экскрементах палочника аннамского никто не проводил.

Объект исследования: отходы жизнедеятельности палочника аннамского.

Предмет исследования: содержание азотистых веществ в смеси песка и помета палочника аннамского.

\section{1. Анализ источников литературы}

Проанализировав несколько школьных учебников биологии [3,4,5,6], по вопросу круговорота азота, мы убедились, что основной является биологическая фиксация азота. Согласно Д.К. Беляеву [4] на 1 га почвы бактериями привносится 25 кг связанного азота в год. Растения усваивают его в виде ионов аммония и нитрат ионов. При этом, по мнению Н. Грина и др. [7] больше всего (в 100 раз) фиксацию азота осуществляют именно бактерии-симбионты бобовых растений (род. Rhizobium). К сожалению, в вышеуказанных учебных изданиях нам не удалось найти данных о количестве тех или иных азотных соединениях для разных видов почв. Ясно только, что в условиях тропического леса круговорот азота происходит значительно быстрее за счет быстрого разложения мертвой органики. Большая часть азота поэтому содержится в биомассе растений [6], а почвы очень бедны его соединениями. Почвы умеренных широт медленнее накапливают азот, но и его вымывание и денитрификация происходит гораздо медленнее. В целом, азот в почве 
находится либо в органическом веществе, либо в минеральном состоянии. Азот органического вещества почвы недоступен растениям, поэтому при анализе почв учитывается именно минеральный (1-5\% от общего азота). Как было сказано выше, чаще всего анализируется нитратная и аммонийная формы. Согласно Н.М. Мудрых и М.А. Алешину [8], обеспеченность нитратным азотом для растений на глубине 0-20 см оценивается следующим образом: меньше 10 мг/кг - очень низкая, 10-15 мг/кг - низкая, 15-20 мг/кг - средняя, больше 20 мг/кг - высокая. При большей глубине (> 20 см) почвенного слоя эти показатели смещаются в меньшую сторону на 5 единиц. Необходимо отметить, что согласно методическим указаниям Минздрава России [9], предельно допустимой концентрацией нитратов в почве является 130 мг/кг. При этом, в абсолютно сухой почве количество нитратов не должно превышать 76,8 мг/кг.

Изучение и анализ количества аммонийного азота осложняется его высокой химической подвижностью и динамичностью концентраций в почве. Возможно, поэтому в вышеуказанных методах [8,9], нет данных о его ПДК и критериев уровня насыщенности в почве. В работе Е.И. Данилиной и др. [10] нам удалось обнаружить данные о содержании аммония в почвах, доведенных до воздушно-сухого состояния. Его концентрация составляет от 13,1 до 14,3 мг/кг. В научной литературе [11] встречается показатель ограниченного загрязнения почв - число Хлебникова (C). Согласно методике его оценки, повышенное содержание аммиака, нитратов и нитритов свидетельствует о процессах самоочищения почвы от азотсодержащих органических веществ.

Необходимо сказать, что круговорот азота связан не только с почвой, но и водными экосистемами. И концентрация азота, как и других элементов требует различных анализов. Вероятно, поэтому, в последнее время наблюдается продвижение товаров для оценки химического состояния, например, аквариумной воды. Здесь и оценка жесткости, водородного показателя $(\mathrm{pH})$, концентрации металлов и неметаллов. Существуют и анализаторы количества аммиака, нитритов и нитратов. Данные вещества считаются опасными для рыб. Азотный цикл в аквариумах идет по аналогичной с почвами схеме $\mathrm{NH}_{4}{ }^{+} \rightarrow \mathrm{NO}_{2}^{-} \rightarrow \mathrm{NO}_{3}^{-}$[12]. Концентрация аммиака/аммония в воде не должна превышать 0,5 мг/л, а нитритов - 0,2 мг/л. Эти данные приводятся для того, чтобы понимать единицы измерения, которые на продаваемых индикаторах зачастую отсутствуют.

Возвращаясь к вопросу о палочниках и их роли в почвообразовании и возможности использования отходов их жизнедеятельности, можно сказать следующее. Как все травоядные насекомые они выделяют значительное количество экскрементов, которые поступают в почву как источник органического азота. Выделяемая ими сухая мочевая кислота [3] включается при помощи бактерий в цикл азота и формирует плодородие 
почвы как источник органического, а затем и неорганического азота. Изучению этого процесса и посвящена данная работа.

Материалы и методы исследования. Работа проходила в 2020 - 2021 учебном году на базе лабораторий химии и биологии Тюменского ПКУ.

Грунт (песчано-пометная смесь) для исследований был получен из инсектария с палочниками. Основу его составлял речной песок. Изучался грунт на наличие ионов аммония $\left(\mathrm{NH}_{4}^{+}\right)$, нитрит ионов $\left(\mathrm{NO}_{2}^{-}\right)$и нитрат ионов $\left(\mathrm{NO}_{3}^{-}\right)$с помощью тестера для оценки аквариумной воды «Vladox» (рис 1). Для оценки были использованы грунты, полученные в разное время, а именно: первый грунт, хранившийся более года (сухой), второй - был взят из террариума в январе 2021 и оценивался во влажном состоянии. В качестве контроля выступал чистый речной песок. Позже анализ содержания нитратов в указанных смесях проводился с помощью прибора «Соэкс Эковизор F4» по методике, указанной в его описании.

Кроме химического анализа грунта, проводили изучение пищевой активности палочников. Для этого были взяты три взрослых палочника и помещены в пятилитровый бокс. Затем проводилось ежедневное взвешивание самих палочников и листвы гибискуса, которая им скармливалась.

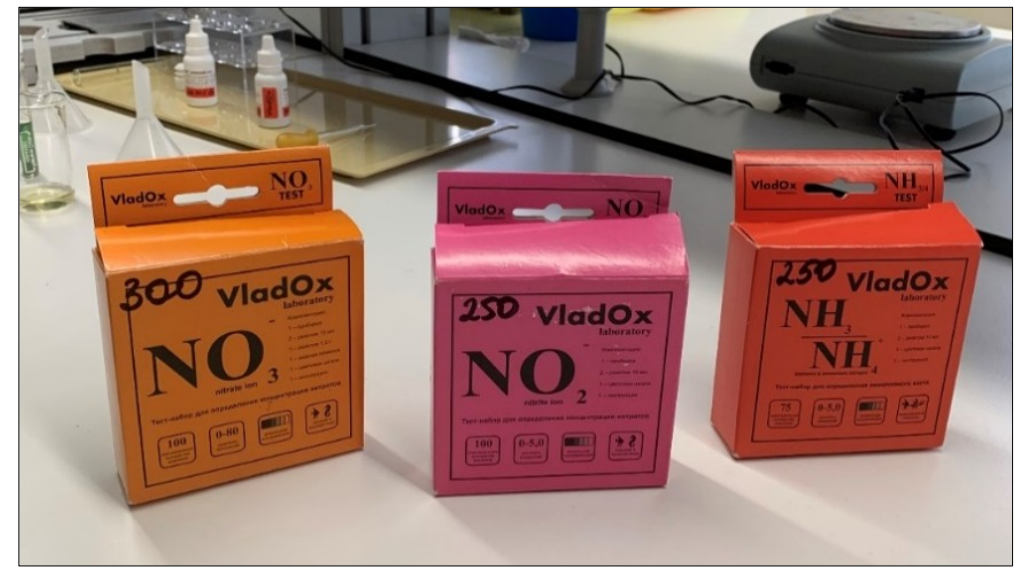

Рис.1. Тестеры для анализа азотистых веществ в воде

Отдельно изучалось влияние грунта с экскрементами палочников на развитие растений. Для этого небольшие побеги - «хохолки» хлорофитума были посажены в контейнеры в двух повторностях по 10 штук (приложение 1). Изучали чистый грунт (песчано-пометную смесь) из инсектария, смесь этого грунта с почвой (1:1) и в качестве контроля - прокаленный речной песок. Через месяц оценивалось количество выросших новых листьев и корней (включая боковые).

Основными методиками для указанных анализов были: «Определение содержания нитратного азота, аммонийного азота и общего азота в воздушно-сухих почвах с помощью 
хлорида кальция в качестве экстрагирующего вещества» [13], «Определение нитратов ионометрическим методом» [14], и указанные выше [8,9].

\section{3. Результаты исследований и их обсуждение}

\section{1. Анализ пищевой активности палочников}

Для того, чтобы оценить скорость формирования отходов палочников и их вклад в создание песчано-помётной смеси (грунта), мы провели следующие наблюдения и расчеты. Седьмого декабря 2021 года три взрослых палочника были взвешены с помощью электронных весов и помещены в пятилитровый бокс (рис 2). Их общая масса составляла 2,6 г. Для питания им были предложены свежие листья гибискуса общей массой 2 г. В течение недели ежедневно (кроме одного воскресенья) проводилось измерение массы палочников и листьев (приложение 2). Общий вес, который набрали палочники, составил 0,5г, а биомасса листьев, съеденная ими, составила 3,4г, то есть по 1,13г на каждого. В сутки один палочник съедает 0,16 г листьев гибискуса, что в месяц составляет 4,86 г, а в год 58,4г. С учетом того, что в основном инсектарии кабинета биологии колония палочников насчитывала в среднем 15 взрослых и 30 нимф палочника, можно оценить вес прибавляемого помета примерно в 850 г за полгода.

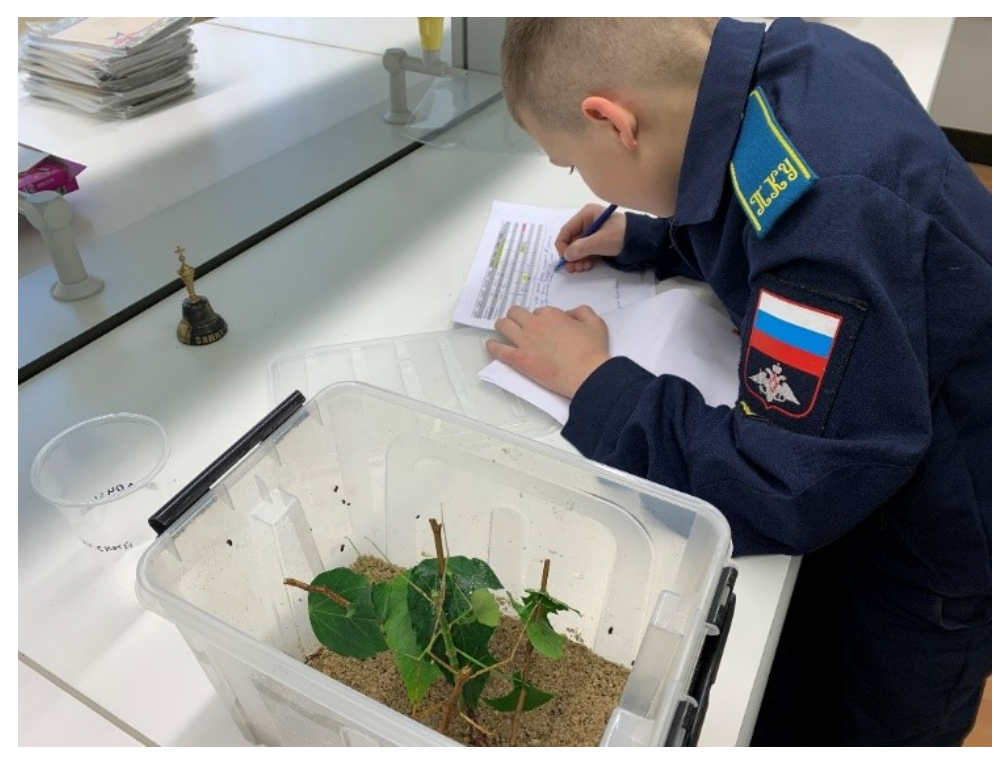

Рис. 2. Закладка опыта на изучение пищевой активности палочников

Накопившись и пропитав песок массой примерно один килограмм, этот помет создал особый грунт в инсектарии. В дальнейшем мы оценивали его как готовую почву для комнатных растений или как удобрение. Необходимо отметить, что процесс формирования вышеуказанного грунта происходил не только за счет питания палочников. Нами отмечалось присутствие плесневых грибов рода Мукор (приложение 3), мельчайших детритофагов коллембол и почвенных клещей. 


\section{2. Изучение воздействие грунта на развитие комнатного растения}

Использование грунта с экскрементами палочников не может применяться на больших площадях в силу ограниченности данного сырья. Поэтому, 29 января 2021 года мы заложили опыт, целью которого было изучение воздействия изучаемого грунта на комнатное растение. В качестве экспериментального растения был взят неприхотливый хлорофитум. Емкости из-под яиц (рис 3) были засыпаны прокаленным песком, чистым грунтом из инсектария и смесью почвы (приложение) и грунта в соотношении 1:1 по объему. Выборка по каждому виду грунта составила 20 экземпляров укороченных побегов (хохолков) указанного растения.

В течение месяца велся полив и наблюдение. В конце февраля провели учет по количеству выросших новых листьев и корней. Для того, чтобы более объективно оценить влияние помета палочников, сразу после этого, в марте был заложен аналогичный опыт с десятью хохолками хлорофитума. В качестве грунта выступала смесь из песка и грунта палочников в соотношении по объему 1:4. Результаты количественных измерений представлены в таблице 1. Наблюдения и анализ результатов показали следующее. Грунт из инсектария не может использоваться как готовая почва для растений хлорофитума. Все посаженные в нем хохолки погибли (рис 4). Мы связываем это с предполагаемым высоким уровнем азота в таком грунте, что соотносится с исследованиями Некрасова Е. [2].

Таблица 1.

Количество (шт.) выросших органов в эксперименте с хлорофитумом

\begin{tabular}{|c|c|c|c|c|c|c|c|c|}
\hline \multirow{2}{*}{ № } & \multicolumn{2}{|c|}{ Грунт } & \multicolumn{2}{|c|}{ Песок } & \multicolumn{2}{|c|}{ Почва + грунт } & \multicolumn{2}{|c|}{ Песок + грунт } \\
\cline { 2 - 9 } & листьян & корни & листья & корни & листья & корни & листья & корни \\
\hline $\begin{array}{c}\text { Преднее } \\
\text { значение }\end{array}$ & 0 & 0 & 1,88 & 1,38 & 1,88 & 0,57 & 1,60 & 2,50 \\
\hline $\begin{array}{c}\text { Ошибка } \\
\text { среднего }\end{array}$ & 0 & 0 & 0,50 & 0,33 & 0,38 & 0,20 & 0,34 & 0,31 \\
\hline $\begin{array}{c}\text { Уровень } \\
\text { надежности } \\
\text { (95,0\%) }\end{array}$ & 0,00 & 0,00 & 1,06 & 0,70 & 0,81 & 0,44 & 0,77 & 0,70 \\
\hline
\end{tabular}

По количеству выросших новых листьев достоверных отличий смеси 1:1 и 1:4 не показали. В тоже время, визуальный анализ (приложение 4) показывает, что общая вегетативная масса листьев значительно выше именно в смеси песка и грунта 1:4. Мы считаем, что такой вариант смешивания положительно влияет на рост уже имеющихся листьев. Анализ числа выросших корней показывает достоверные отличия смесей от контроля. В смеси “почва и грунт 1:1” наблюдали очень незначительное количество появившихся придаточных корней, но их длина субъективно выше контроля (рис 3). В 
смеси “песок+грунт1:4” среднее количество корней достоверно превышает показатели контрольной группы. Также мы наблюдали значительно большую длину этих корней. Полученные результаты эксперимента позволяют сделать вывод о возможности использования помета палочников из инсектария, но только виде дополнения к основному субстрату. Важно отметить, что таким субстратом может быть обычный песок. В перспективе возможно проведение эксперимента направленного на изучение изменения биомассы выращиваемых растений.
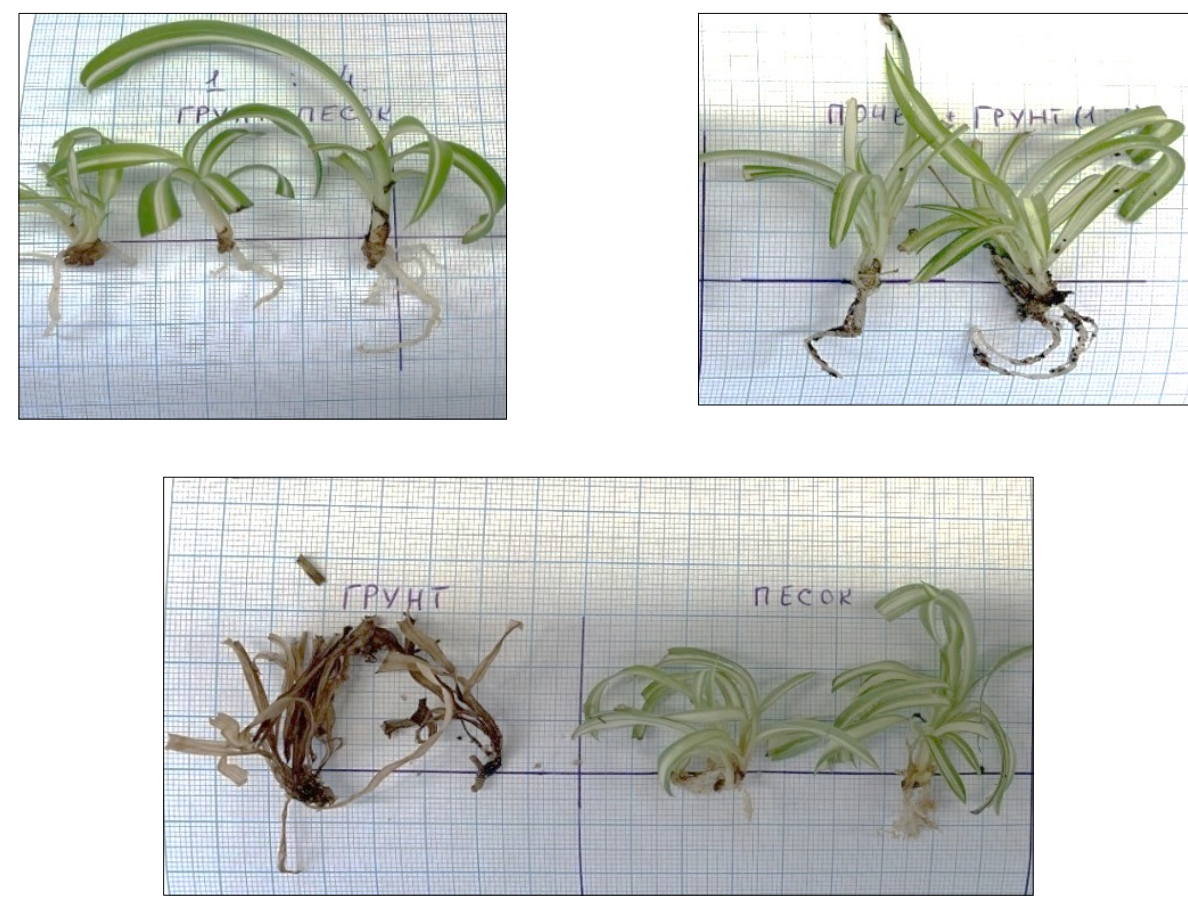

Рис. 3. Результаты опытов с хлорофитумом (справа вверху: почва+грунт 1:1)

\section{3. Исследование грунта на наличие ионов аммония $\left(\mathrm{NH}_{4}^{+}\right)$, нитрит $\left(\mathrm{NO}_{2}{ }^{-}\right)$и нитрат $\left(\mathrm{NO}_{3}{ }^{-}\right)$ионов}

Как уже было сказано выше, химическое исследование грунта проводилось с помощью тестера для оценки аквариумной воды «Vladox» в несколько этапов:

Отбор проб. 1. Пробы в воздушно-сухом состоянии измельчили, пропустили через сито с круглыми отверстыми диаметром 1-2 мм и поместили в коробки. Затем отобрали из коробки ложкой 3 пробы по 20 г на анализ, предварительно перемешав почву на всю глубину коробки.

2. Пробы в состоянии естественной влажности тщательно перемешали, распределили слоем толщиной не более 1 см на ровной поверхности и также отобрали 3 пробы по 20 г из десяти точек для проведения анализа.

3. В качестве эталона сравнения использовали речной песок: 3 пробы по 20 г

Приготовление почвенной вытяжки. Для получения почвенной вытяжки в качестве экстрагирующего вещества использовали дистиллированную воду (определение нитритов 
и аммонийного азота) и раствор алюмокалиевых квасцов (определение концентрации нитратов).

Раствор алюмокалиевых квасцов с массовой долей $1 \%$ приготовили согласно методике [13], из расчета 10 г алюмокалиевых квасцов, взвешенных с погрешностью не более 0,1 г на 1000 мм раствора. Пробы почвы массой 20,0 г поместили в конические колбы. К пробам прилили по 50 мл экстрагирующего раствора. Пробу с раствором перемешали на электромеханической мешалке в течение 3 мин (приложение 5). Полученные суспензии оставили на 24 часа для экстрагирования.

По истечении указанного времени провели фильтрование. Далее полученную почвенную вытяжку исследовали на наличие ионов аммония $\left(\mathrm{NH}_{4}^{+}\right)$, нитрит $\left(\mathrm{NO}_{2}^{-}\right)$и нитрат $\left(\mathrm{NO}_{3}{ }^{-}\right)$ионов. К нашему сожалению, большая часть исследования была сорвана по причине некачественных, просроченных анализаторов «Vladox». Поэтому мы смогли оценить только уровень нитратов по предлагаемой производителем цветовой шкале для визуально-колориметрического определения концентрации ионов (рис 4).

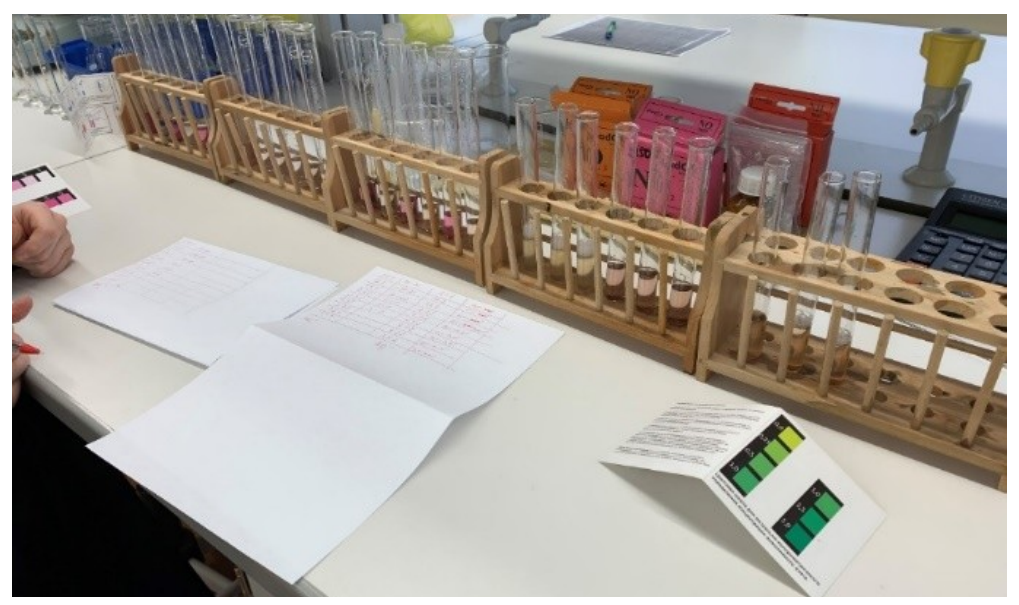

Рис.4. Использование визуально-колориметрической шкалы

Для проведения опыта в пробирку налили 5 мл почвенной вытяжки. Затем поочередно добавили по 4 капли реактивов №1 и №2 (предварительно взбалтывая каждый флакон с реактивом) и одну мерную ложку порошкообразного реактива №3. После добавления каждого реактива содержимое пробирки закрывали пробкой и тщательно перемешивали. Открытую пробирку поместили в штатив и подождали 7 минут. По истечении времени сравнили цвет тестируемой вытяжки с колориметрической шкалой и определили содержание нитратов в почвенной вытяжке. Данные представлены в таблице 2.

Концентрация нитратов в исследуемых образцах грунта

\begin{tabular}{|l|c|c|c|}
\hline \multirow{2}{*}{ Тип грунта } & \multicolumn{3}{|c|}{ Концентрация нитратов, мг/л } \\
\cline { 2 - 4 } & 1пробирка & 2 пробирка & 3 пробирка \\
\hline Сухой грунт & 80 & 80 & 80 \\
\hline
\end{tabular}




\begin{tabular}{|l|c|c|c|}
\hline Влажный грунт & $50-80$ & $50-80$ & $50-80$ \\
\hline Песок & 5 & 5 & 5 \\
\hline
\end{tabular}

Данные таблицы наглядно показывают, с одной стороны, явное наличие и высокое количество нитратов в грунтах с пометом палочников. При этом, в сухом годичном грунте наблюдается большее количество нитратов. Согласно литературным данным [9], эти показатели критичны для сухих почв и приближаются к таковым при пересчёте на кг веса. Но колориметрическая шкала, на наш взгляд, не дает объективных данных. Мы приобрели прибор для оценки количества нитратов Соэкс эковизор F4 (приложение 6). Прибор позволяет оценивать наличие нитрат-ионов в продуктах питания. Поэтому мы решили провести изучение наших грунтов в двух направлениях. Сначала, для сравнения с предыдущими показателями мы получили водные вытяжки, полученные по аналогии с предыдущими. Затем, мы провели измерения, смочив смеси и оценив количество нитратов во влажном состоянии в пяти повторностях. Результаты представлены в таблице 3.

Таблица 3.

Показания прибора Соэкс в изученных смесях*

\begin{tabular}{|c|c|c|c|c|c|c|}
\hline \multirow{2}{*}{ № } & \multicolumn{2}{|c|}{ Нитраты в водных вытяжках, мг/кг } & \multicolumn{3}{|c|}{ Нитраты в смоченных грунтах, мг/кг } \\
\cline { 2 - 7 } & Песок & $\begin{array}{c}\text { Влажный } \\
\text { грунт }\end{array}$ & $\begin{array}{c}\text { Сухой } \\
\text { грунт }\end{array}$ & Песок & $\begin{array}{c}\text { Влажный } \\
\text { грунт }\end{array}$ & Сухой грунт \\
\hline 1 & $<10$ & 40 & 164 & $<10$ & 14 & 150 \\
\hline 2 & $<10$ & 34 & 166 & $<10$ & 14 & 155 \\
\hline 3 & $<10$ & 29 & 168 & $<10$ & 15 & 170 \\
\hline 4 & $<10$ & 31 & 168 & $<10$ & 15 & 173 \\
\hline 5 & $<10$ & 39 & 168 & $<10$ & 15 & 193 \\
\hline Ср.знач. & - & $34,6 \pm 2,2$ & $166,8 \pm 0,8$ & - & $14,6 \pm 0,2$ & $168,2 \pm 7,6$ \\
\hline
\end{tabular}

* - измерения указаны при настройке прибора на варианте «арбуз». Полная версия измерений в приложении 7,8.

С учетом того, что погрешность измерений прибора составляет 10 единиц, можно сделать следующие выводы. Между тремя исследуемыми смесями существует достоверная разница по количеству нитратов при обоих вариантах измерения. В песке прибор всегда показывал отметку ниже 10мг/кг. Это указывает на некоторое сходство с ранее проведенными колориметрическими показателями. При разных настройках эковизора в относительно свежем влажном грунте концентрация нитратов варьировала от 14 до 18 мг/кг (см приложение 7), а в более выдержанном сухом - $154-173$ мг/кг. Существенная разница этих цифр при разных способах оценки свидетельствует о явных процессах нитратообразования в смеси песка и помета палочников. Заметна разница и в концентрации нитрат-ионов при разных способах измерения влажного - незрелого грунта. 
В вытяжке значения составили в среднем 32 мг/кг, а в смоченном грунте - 14,6 -16,8 единиц. Поэтому, вопрос точности этих измерений пока остается открытым. Учитывая, что в абсолютно сухой почве количество нитратов не должно превышать 76,8 мг/кг [9], становится понятной гибель побегов хлорофитума в чистой смеси без разбавления.

\section{Заключение}

Анализ литературных источников, проведенные эксперименты и наблюдения позволили сделать следующие выводы:

1. Палочник аннамский - растительноядное насекомое, которое позволяет при постоянном кормлении в искусственных условиях получать порядка полутора кг помета за год в террариуме объёмом 30 л и численности колонии 40-50 особей;

2. Опыт с комнатным растением хлорофитумом показал достоверное увеличение количества формируемых придаточных корней в смеси грунта и песка 1:4 по сравнению с контролем;

3. Смешиваясь с песком, помет формирует смесь, которая может использоваться как почвенная первооснова, но только при условии разбавления с другими грунтами. Оптимальная пропорция при этом - 25\% песка: 75\% смеси;

4. Химический анализ содержания нитратов при помощи колориметрического метода показал высокую концентрацию таковых в грунте с пометом палочников (более 50 мг/л водной вытяжки);

5. Данные прибора Соэкс эковизор F4 во влажных и сухой смесях позволили уточнить эти данные и показали значительную (более 10 раз) разницу. Доля нитратов в отлежавшейся сухой смеси песка и помета Палочника аннамского составила более 160 мг/ гК.

В дальнейшем, по мере появления качественных реактивов, мы планируем изучить количественные характеристики нитритов и аммония в помете палочника.

Возвращаясь к идее создания экодомов замкнутого цикла и возможности использования палочников как источников создания органического и неорганического компонентов почвы, можно утвердительно сказать, что эти насекомые очень удобный и продуктивный с точки зрения почвообразовательной функции объект. При использовании их помета нужно необходимо соблюдать меры предосторожности из-за высокой концентрации нитратов.

\section{Источники литературы:}

1. Носков, Д. А. Исследование модификационной изменчивости палочника аннамского по окраске тела/[Электронный ресурс] / Д.А.Носков, Е.П.Саранчин. Режим доступа: https://preprints.ru/article/510 
2. Некрасов, Е.В. Отходы жизнедеятельности палочника аннамского как удобрение / [Электронный ресурс]/ Е.В. Некрасов, Саранчина Н.В. Режим доступа: https://preprints.ru/article/511

3. Беляев, Д.К. Общая биология: учебник для 10-11 кл. общеобразовательных учреждений/[Текст]/ Д.К.Беляев, П.М. Бородин, Н.Н Воронцов и др. - 5-е изд.: М.:Просвещение, 2005. -304c.

4. Захаров, В.Б. Общая биология: учебник для 10-11 кл. общеобразовательных учебных заведений/[Текст]/ В.Б. Захаров, С.Г. Мамонтов, Н.И. Сонин. - М.:Дрофа, 2001. 624c.

5. Полянский, Ю. И. Общая биология: учебник для 10-11 кл. общеобразовательных учреждений /[Текст]/ Ю.И.Полянский, А.Д. Браун, Н.М. Верзилин и др. М.:Просвещение, 1998. - 287с.

6. Рувинский, А.О. Учебник для 10-11 кл. с углубленным изучением биологии /[Текст]/ Рувинский А.О., Л.В. Высоцкая, С.М. Глаголев. - М.:Просвещение, 1993. - 544с.

7. Грин,Н. Биология [Текст] / В 3-х томах/ Н. Грин, У. Стаут, Д. Тейлор; ред.Р.Сопера. - М.:Мир, 1990 - Т.3. - 325с.

8. Мудрых, Н.M. Пособие к лабораторным занятиям по агрохимии/ [Электронный ресурс]/ Н.М. Мудрых, М.А. Алёшин.: Методическое пособие для студентов специальности 110201.65 «Агрономия», Режим доступа: http://www.seluk.ru/agro/461128-1kafedra-agrohimii-mudrih-aleshin-posobie-laboratornim-zanyatiyam-agrohimii-metodicheskoeposobie-dlya-studentov-s.php

9. Методические указания МУ 2.1.7.730-99. / [Электронный ресурс]/ Гигиеническая оценка качества почвы населенных мест. Режим доступа: https://docs.cntd.ru/document/1200003852

10. Данилина, Е.И. Определение обменного и водорастворимого аммония в почвах модифицированными индофенольными методами/ [Текст]/ Е.И. Данилина, В.В.Рогулин, Е.А. Бабичева. Режим доступа: https://cyberleninka.ru/article/n/opredelenie-obmennogo-ivodorastvorimogo-ammoniya-v-pochvah-modifitsirovannymi-indofenolnymi-metodami/viewer

11. Сорокин, Н.Д. Пособие по вопросам изучения загрязнённых земель и их санации / [Электронный ресурс]/ Н.Д. Сорокин, Е.Б. Королева, Е.В. Лосева и др. Режим доступа: https://www.ecoprofi.info/docs/book contaminated land and sanation.pdf

12. Азотный цикл. Синодонтис. Качество воды для аквариума/[Электронный ресурс]/Режим доступа: http://www.sinodontis.ru/catalog/kachestvo-vody-dlya-akvariuma

13. ГОСТ 26951-86. Определение нитратов ионометрическим методом/[Текст] /Л.М.Державин и др., Разработан Государственным агропромышленным комитетом СССР,1987. - 9с.

14. ГОСТ Р 53219-2008.Качество почвы. Определение содержания нитратного азота, аммонийного азота и общего азота в воздушно-сухих почвах с помощью хлорида кальция в качестве экстрагирующего вещества/[Электронный ресурс]/ подготовлен 
Государственным научным учреждением «Всероссийский научно-исследовательский институт агрохимии имени Д.Н. Прянишникова». Режим доступа: http://www.vashdom.ru/gost/53219-2008/ 


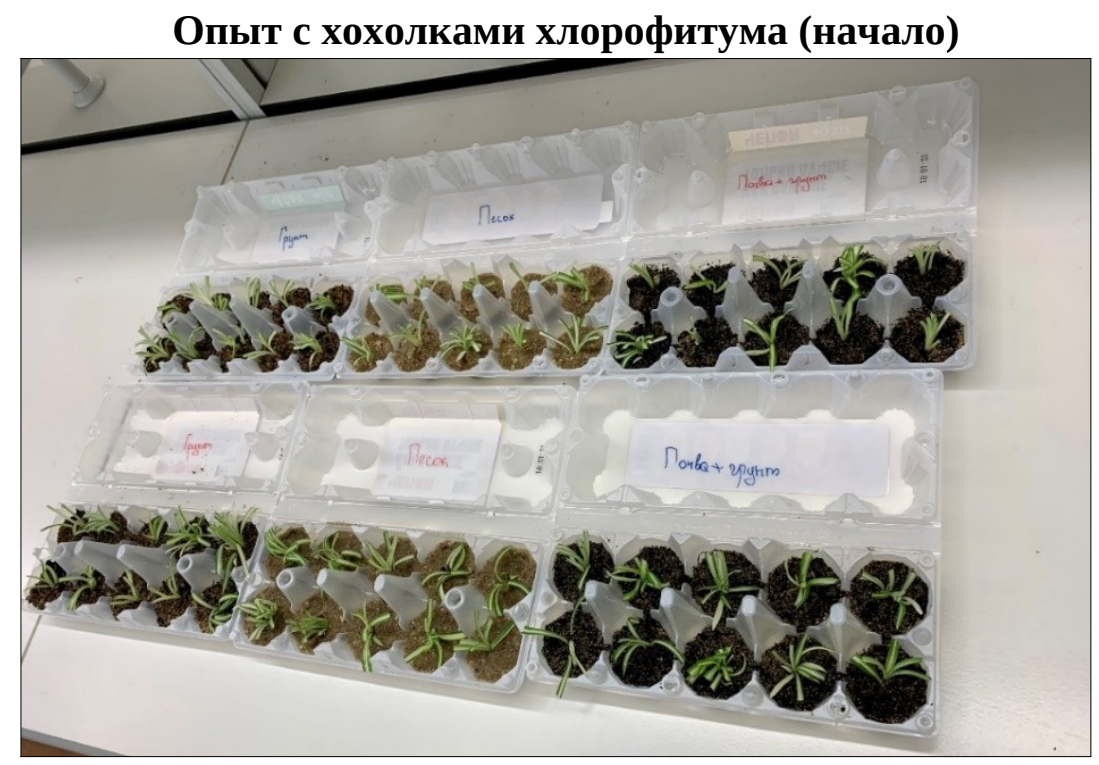

Приложение 1

Приложение 2

Динамика изменения массы(г) листвы и палочников

\begin{tabular}{|l|c|c|c|c|c|c|}
\hline Да & 0 & 0 & 0 & 1 & 1 & 1 \\
ты & 7. & 8. & 9. & 0. & 2. & 3. \\
& 1 & 1 & 1 & 1 & 1 & 1 \\
& 2. & 2. & 2. & 2. & 2. & 2. \\
& 2 & 2 & 2 & 2 & 2 & 2 \\
& 0 & 0 & 0 & 0 & 0 & 0 \\
& 2 & 2 & 2 & 2 & 2 & 2 \\
& 0 & 0 & 0 & 0 & 0 & 0 \\
\hline 1- & & & & & & \\
й & & & & & & \\
па & 1, & 1, & 1, & 1, & 1, & 1, \\
ло & 2 & 1 & 3 & 3 & 4 & 4 \\
чн & & & & & & \\
ик & & & & & & \\
\hline 2- & & & & & & \\
й & & & & & & \\
па & 0, & 0, & 0, & 0, & 0, & 0, \\
ло & 8 & 8 & 9 & 9 & 9 & 9 \\
чн & & & & & & \\
ик & & & & & & \\
\hline 3- & & & & & & \\
й & & & & & & \\
па & 0, & 0, & 0, & 0, & 0, & 0, \\
ло & 6 & 7 & 7 & 6 & 8 & 8 \\
чн & & & & & \\
ик & & & & & & \\
\hline О & 2, & 2, & 2, & 2, & 3, & 3, \\
б & 6 & 6 & 9 & 8 & 1 & 1 \\
щ & & & & & & \\
ая & & & & & & \\
ма & & & & & & \\
\hline
\end{tabular}




\begin{tabular}{|l|l|l|l|l|l|l|}
\hline сс & & & & & & \\
а & & & & & & \\
па & & & & & & \\
ло & & & & & & \\
чн & & & & & & \\
ик & & & & & & \\
ов & & & & & & \\
\hline Л & 6, & 5, & 5, & 4, & 3, & 2, \\
ис & 2 & 6 & 2 & 5 & 4 & 8 \\
тв & & & & & & \\
а & & & & & & \\
\hline
\end{tabular}

Приложение 3.

Мукор на стеблях малины из террариума с палочниками

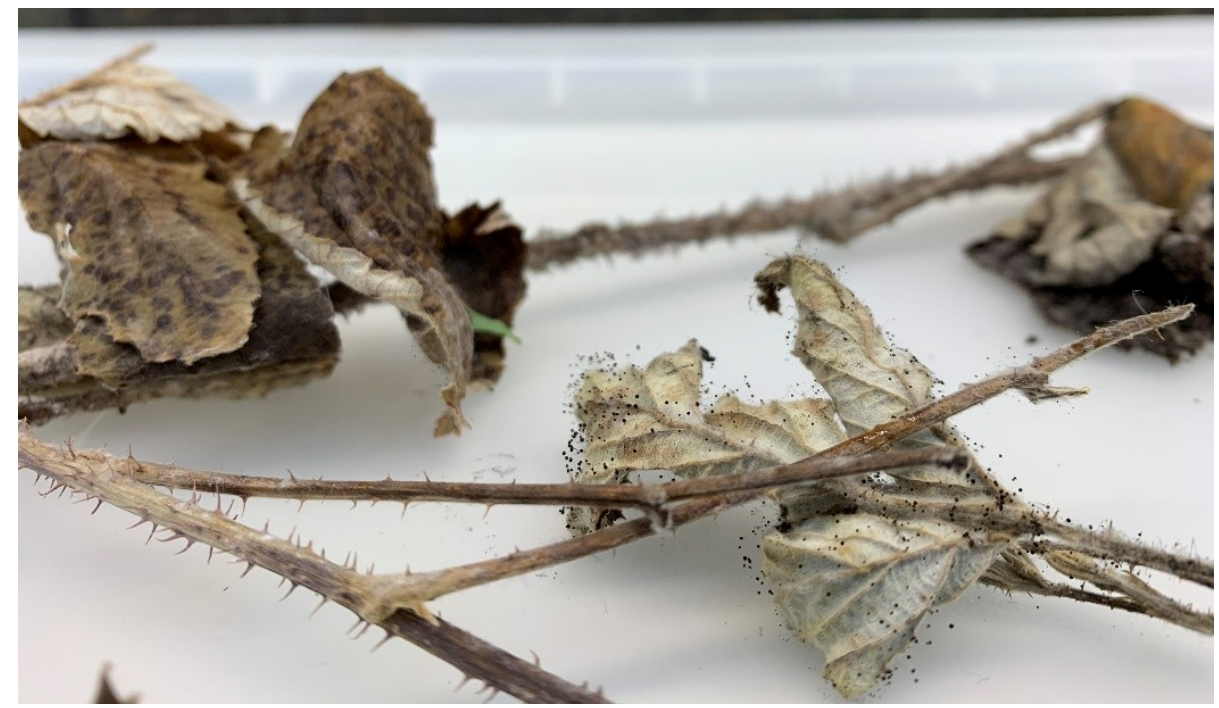

Приложение 4 


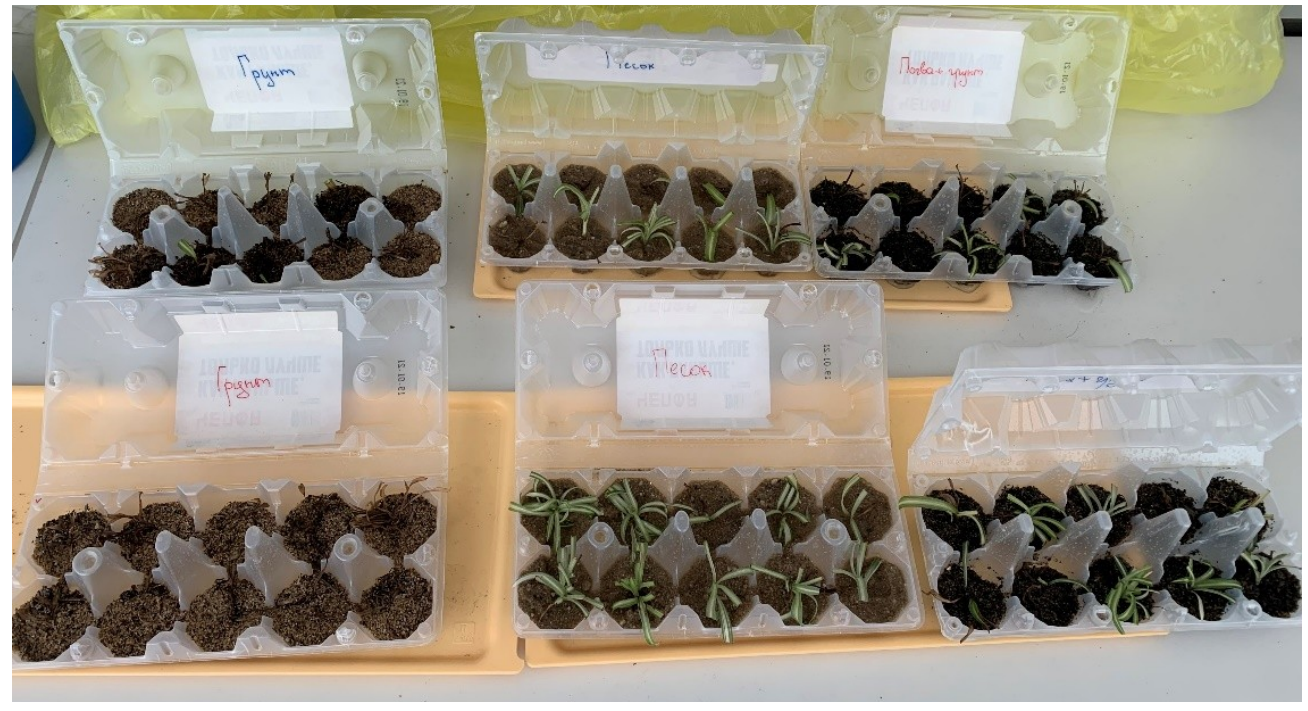

Приложение 5 Получение суспензий на электромеханических вытяжках 


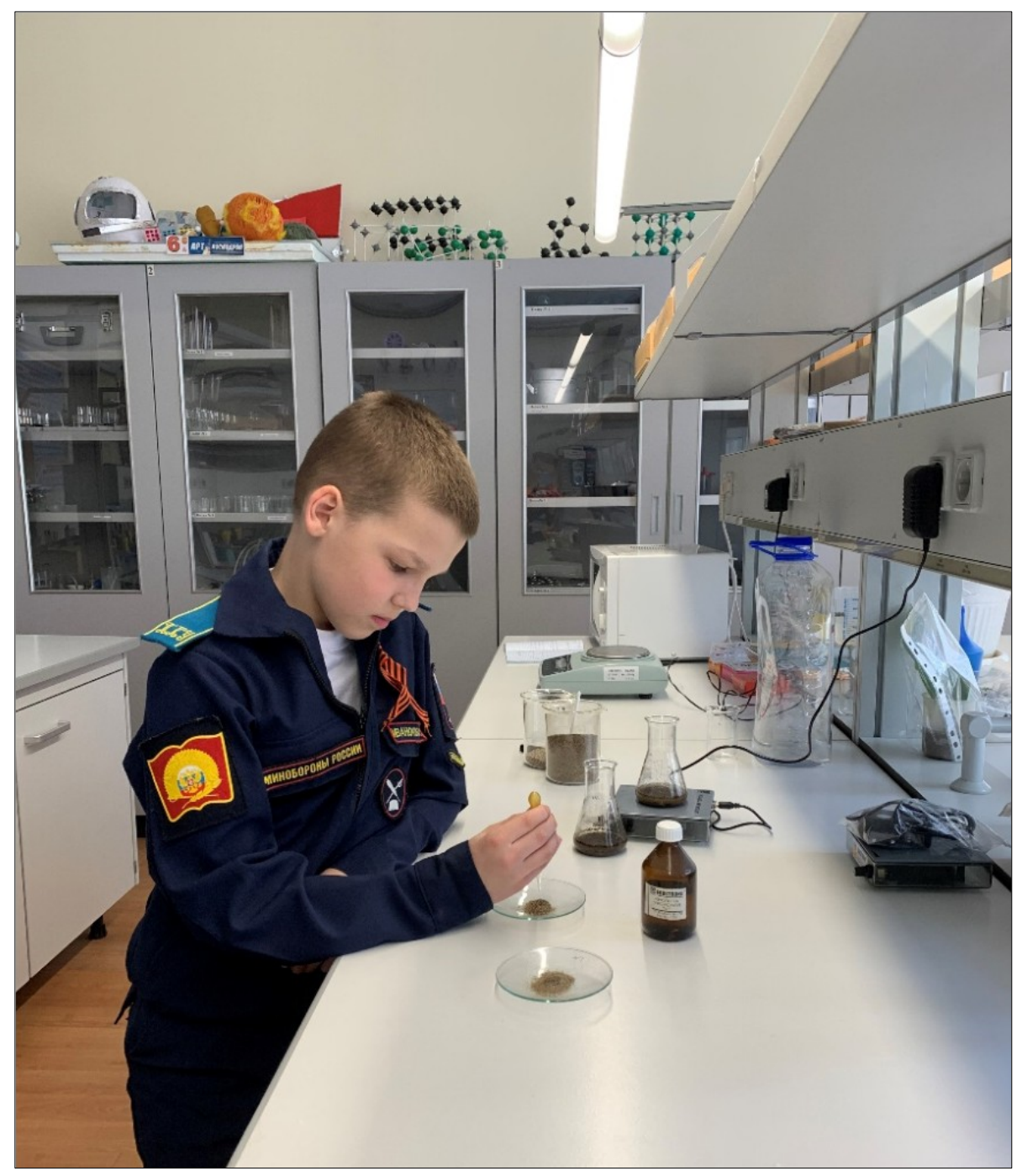


Приложение 6

Измерение концентрации нитратов с помощью прибора Соэкс

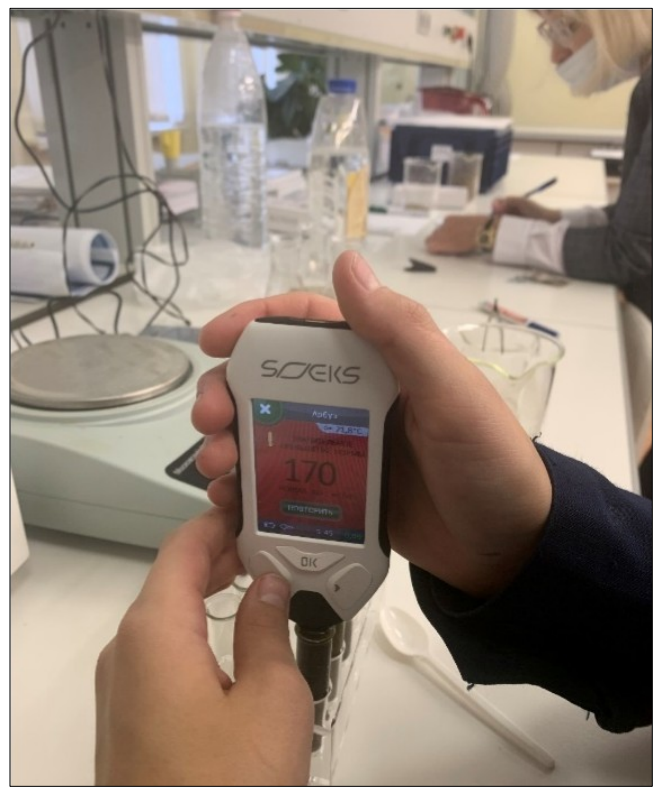

Приложение 7

Концентрация нитратов(мг/кг) по данным прибора Соэкс при разных настройках в смоченных смесях

\begin{tabular}{|c|c|c|c|c|c|c|}
\hline \multirow{2}{*}{$\begin{array}{c}\text { № } \\
\text { изм }\end{array}$} & \multicolumn{2}{|c|}{ Сухой грунт } & \multicolumn{2}{|c|}{ Песок } & \multicolumn{2}{|c|}{ Влажный грунт } \\
\cline { 2 - 7 } & арбуз & кабачок & арбуз & кабачок & арбуз & кабачок \\
\hline 1 & 150 & 164 & $<10$ & $<10$ & 14 & 16 \\
\hline 2 & 155 & 173 & $<10$ & $<10$ & 14 & 16 \\
\hline 3 & 170 & 177 & $<10$ & $<10$ & 15 & 17 \\
\hline 4 & 173 & 142 & $<10$ & $<10$ & 15 & 17 \\
\hline 5 & 193 & 139 & $<10$ & $<10$ & 15 & 18 \\
\hline Ср.знач & $\mathbf{1 6 8 , 2 \pm 7 , 6}$ & $\mathbf{1 5 9 \pm 7 , 9}$ & - & - & $\mathbf{1 4 , 6 \pm 0 , 2}$ & $\mathbf{1 6 , 8 \pm 0 , 4}$ \\
\hline
\end{tabular}

Приложение 8

Концентрация нитратов(мг/кг) по данным прибора Соэкс при разных настройках в вытяжках*

\begin{tabular}{|c|c|c|c|c|c|c|}
\hline \multirow{2}{*}{$\begin{array}{c}\text { № } \\
\text { изм }\end{array}$} & \multicolumn{3}{|c|}{ Сухой грунт } & \multicolumn{3}{c|}{ Влажный грунт } \\
\cline { 2 - 7 } & арбуз & кабачок & шампиньон & арбуз & кабачок & шампиньон \\
\hline 1 & 164 & 165 & 154 & 40 & 30 & 28 \\
\hline 2 & 166 & 165 & 155 & 34 & 32 & 37 \\
\hline 3 & 168 & 165 & 154 & 29 & 30 & 35 \\
\hline 4 & 168 & 164 & 158 & 31 & 31 & 31 \\
\hline 5 & 168 & 173 & 147 & 39 & 29 & 29 \\
\hline Ср.знач & $\mathbf{1 6 6 , 8} \pm \mathbf{0 , 8}$ & $\mathbf{1 6 4 , 4 \pm \mathbf { 1 , 7 }}$ & $\mathbf{1 5 3 , 6 \pm \mathbf { 1 , 2 }}$ & $\mathbf{3 4 , 6 \pm 2 , 2}$ & $\mathbf{3 0 , 4 \pm 0 , 2}$ & $\mathbf{3 2 \pm \mathbf { 1 , 7 }}$ \\
\hline
\end{tabular}

* без учета чистого песка, в котором все значения меньше 10мг/кг 